\title{
Determination of cyber accessibility of teacher made tests/exams
}

\section{Gulden Ozdemir (iD) 1 , Atilla Ozdemir (iD) 2, , Selahattin Gelbal (iD) ${ }^{3}$}

\author{
${ }^{1}$ Ministry of National Education, Ankara, Turkey \\ ${ }^{2}$ Süleyman Demirel University, Faculty of Education, Department of Mathematics and Science Education, Isparta, \\ Turkey \\ ${ }^{3}$ Hacettepe University, Faculty of Education, Department of Educational Sciences, Ankara, Turkey
}

\author{
ARTICLE HISTORY \\ Received: Aug. 19, 2020 \\ Revised: Apr. 03, 2021 \\ Accepted: May 26, 2021 \\ Keywords: \\ Teacher-made exams, \\ Cyber accessibility, \\ Exam reliability, \\ Teacher made tests/exams, \\ Assessment.
}

\begin{abstract}
This study aims at determining the cyber accessibility of teacher-made exams by analyzing the teachers', students', and parents' views on this subject. To fulfill this purpose, 60 exam papers in 4 different courses, including Turkish, Mathematics, Science, Social Studies/Atatürk's Principles and Revolutions, were examined through the technique of document analysis. Also, nine teachers, nine students, and nine parents were interviewed through semi-structured interview forms. According to the results, the level of cyber accessibility of secondary school teacher-made exams were; $87 \%$ for Turkish, $51 \%$ for mathematics, $99 \%$ for Science, and $88 \%$ for Social Studies/Atatürk's Principles and Revolutions courses. The highest level of cyber accessibility was found in multiple-choice and openended questions for Turkish courses, true-false questions for mathematics courses, open-ended, true-false, matching, and gap-filling questions for the Science courses and open-ended questions for Social Studies/Atatürk's Principles and Revolutions courses. Students and parents stated that they make use of cyber accessible websites while preparing for teacher-made exams. On the other hand, teachers indicated that they perceived themselves incompetent in assessment and evaluation.
\end{abstract}

\section{INTRODUCTION}

Education is a broad system where the input, process, output, and feedback mechanisms interact with each other. In the educational system, one of the most effective ways to provide feedback to students, parents, and school; in short, to all the stakeholders of educational process is the exams (Baykul, 2010). The knowledge and skills of individuals about a particular area are tested through exams (Büyüköztürk, 2016).

In this respect, according to the expertise of the author, there are two types of exams: teachermade exams and standard exams. Teacher-made exams consist of tests used by teachers at school in the classroom. On the other hand, standard exams are exams prepared by experts or a measurement institution by following test development processes (Kilmen, 2014).

The results of teacher-made exams are used to provide feedback on missing or incorrect learning and the creation of students' End-of-the-Year Achievement Score (EYAS) and School

\footnotetext{
*CONTACT: Atilla ÖZDEMIR $\bigotimes$ atillaozdemir@sdu.edu.tr Education, Department of Mathematics and Science Education, Isparta, Turkey
} 
Achievement Score (SAS). Besides, according to The Guidelines for Transition to Secondary Education (MEB, 2019, p. 7-8) prepared by the Ministry of National Education (MEB) for the students who take the 'Central Examination for Secondary Education Institutions that will Receive Students by Exam', which is an exam applied for the transition from secondary school to high school;

\section{“1.5.1. Central Placement}

b) In case the central examination score is equal in the schools that accept students by examination; placement is made by looking at the School Achievement Score (SAS) superiority, the End-of-the-Year Achievement Score (EYAS) superiority (...) in the 8th, 7th and 6th grades, respectively.

1.5.2. Local Placement

a) Local placement (...) is done according to the students' residence addresses and the superiority of school achievement score (...) criteria, respectively. In case of equality in the evaluation, the placement will be made by looking at the success score of the 8 th, 7 th and 6 th grades respectively."

Accordingly, teacher-made exam results also play an effective role in students' transition to higher education. In the German education system, there is no central examination for the transition from primary to secondary education, but placement is made based on the German and mathematics grade averages and observations conducted by the teacher (Aytaç, 1999; Faust, 2011; as cited in Göçkan, 2019, s.64). In the Singapore education system, students' placement into eligible secondary education programs is fulfilled by the 'Primary School Leaving Examination (PSLE)'. This test includes English, mother tongue, mathematics, and science questions. In the Finnish education system, academic achievements; and for vocational schools, work experiences are taken into consideration for transferring students to secondary education (Bal \& Başar, 2014). It is possible to see that the results of teacher-made exams are determinant in the examples of transitions between educational stages in different countries as well. For this reason, teacher-made exams, which play an essential role in making decisions about the educational career of students, must be valid, reliable, and fair.

Teacher-made exams include different types of questions such as multiple-choice, open-ended, true-false, matching, and gap-filling. Teachers are expected to prepare these questions based on the objectives and achievements stated in the curriculum. However, it is assumed that the cyber accessibility of the questions in teacher-made exams will affect the reliability of the exam results; and thus, may lead to assessment and evaluation problems. Although the term cyber can be described as "something that exists in the form of software, not physical" as a computer term, it is used synonymously with the term virtual in daily life and is generally defined as an adjective used to mean belonging to the internet (Özdemir \& Şahin; 2005). The increase in the use of information communication technologies has also increased access to information and communication between people. Computer use and internet access rates have increased due to these developments (Shariff \& Gouin, 2005; Wang et al., 2009). Thus, the earth transformed into a kind of noosphere, a planet-wide consciousness was arisen, woven from one side of the globe to the other with fibers and networks. This change caused by the development of communication and internet technologies in our lives has carried a large part of our real-life to the cyber world and educational activities have been significantly affected by this change (Ateş, 2016). There are many educational platforms that share content for students and teachers in cyberspace. On these platforms; annual and daily course plan examples, written exam questions, tests, lecture videos, and many other similar contents can be accessed. In many cyberaccessible platforms with these contents, it is seen that teacher-made exam questions are shared for different grade levels and for different courses, including information such as the name of the course, period of education, name or title of the exam. In this study, the concept of cyber accessibility was defined by the researchers as accessing teacher-made exam questions through digital media such as the internet. If teacher-made exams are not prepared in a unique way and consist of questions that exist on any website before, this will cause advantages and 
disadvantages for students who could and could not access these questions beforehand. As a result, the grades of the students who have been able to reach the exam questions will not reflect the truth. This situation will negatively affect the reliability of the exam results as well as the student achievement rankings in central exams where school achievement scores become important. Therefore, it will also pose a threat to the fairness of the decisions to be made about the transition of individuals to higher education. Fairness is a fundamental issue of validity and requires attention in all stages of test development and use (AERA et al., 2014).

When the relevant literature is reviewed, it is generally seen that the researchers have examined teacher-made exams taking Bloom's taxonomy into consideration (Ardahanlı, 2018; Çalışkan \& Uymaz, 2019; Turan, 2017), and evaluated them regarding the target behaviors (Demircioğlu \& Demircioğlu, 2009; Zorbaz, 2005). It is also possible to see other studies that compare teacher-made exams with Central Exam questions, PISA questions, and Central Common Exam scores (Akar, 2019; Bakırc1, 2019; Önder, 2016; Sınac1, 2019). However, no research that determines the cyber accessibility of teacher-made exams and examines the opinions of teachers, students, and parents has been observed in the reviewed literature.

As a consequence, it is necessary to define the cyber accessibility of teacher-made exams that directly affect students' lives and indirectly their social layers. In a similar vein, this research also aims to obtain the teachers', students', and parents' views regarding cyber accessibility of teacher-made exams. This study is significant since it will make a unique contribution to the literature determining the existing situation of the cyber accessibility of teacher-made exams. Additionally, different perspectives will be presented by taking the opinions of teachers, students, and parents on this subject. It is expected that the research results will offer significant benefits to the stakeholders of education and further studies as a source. Therefore, in this study, it is aimed at determining the cyber accessibility of teacher-made exams and examining the teachers', students', and parents' opinions on the subject. For this purpose, answers to the following questions have been sought;

1. What is the cyber accessibility level of the secondary School Turkish, mathematics, science, and social studies/Atatürk's principles and revolutions courses' teacher-made exams?

2. Regarding the cyber accessibility of secondary school teacher-made exams;

a) what are the teachers' opinions?

b) what are the students' opinions?

c) what are the parents' opinions?

\section{METHOD}

In this section, information about research design, data source, study group, data collection tools and techniques, data collection, and data analysis have been presented. This study adopts phenomenology design, one of the qualitative research methods. Qualitative research, according to Yıldırım \& Şimşek $(2013$, p.46) is defined as "the research in which qualitative data collection methods such as observation, interview, and document analysis are used, and a qualitative process for the realization of perceptions and events realistically and holistically in the natural environment". The research is a two-stage qualitative study consisting of document analysis and descriptive analysis stages for interviews. In the first stage, the document review of teacher-made exam questions belonging to the Turkish, mathematics, science, and social studies/Atatürk's principles and revolutions courses have been conducted. In the second stage, the opinions of teachers, students, and parents on cyber accessibility of teacher-made exam questions were examined in-depth via descriptive analysis. The research models employed within the study are presented in Table 1 . 
Table 1. Stages of the research model.

\begin{tabular}{ll}
\hline Stages & \multicolumn{1}{c}{ Research Model } \\
\hline Stage I & Document Review \\
\cline { 2 - 2 } & $\begin{array}{l}\text { Investigation of cyber accessibility of teacher-made exams for Turkish, mathematics, sci- } \\
\text { ence and social studies/Atatürk's principles and revolutions courses }\end{array}$ \\
\hline Stage II & \multicolumn{1}{c}{ Descriptive Analysis } \\
\cline { 2 - 2 } & $\begin{array}{l}\text { Examining the opinions of teachers, students and parents regarding the cyber accessibility } \\
\text { of teacher-made exam questions with descriptive analysis }\end{array}$ \\
\hline
\end{tabular}

\subsection{Source of Data}

The teacher-made exams of Turkish, mathematics, science, and social studies/Atatürk's principles and revolutions courses make up the first stage of the study. They were gathered from three different secondary schools in Ankara that have volunteered to participate in the study.

\subsubsection{Study group}

In the second stage, the study group of the research has been determined. Criterion sampling, one of the purposive sampling methods, has been used to determine the study group. In criterion sampling, a study group is formed regarding the person, event, object, or situation with the appropriate qualifications for the problem statement (Patton, 2005). Accordingly, a total of nine people in each group, thrice teachers, parents, and students from each of the three volunteer schools were determined as the study group. Furthermore, in order to ensure the diversity of the study group, it is essential to take into account the differences in genders, branches, educational status, and professional seniority of the teachers that are interviewed. As for parents, however, the differences in gender and education status have been considered. And lastly, for students, the gender and class level differences have been taken into consideration.

Within the framework of the research's ethics, instead of using the names of teachers, parents, and students who participated in the research, participants were coded. Teachers were coded as $\mathrm{T} 1, \mathrm{~T} 2, \mathrm{~T} 3, \ldots \mathrm{T} 9$, parents were coded as P1, P2, P3,... P9 and students were coded as S1, S2, S3,... S9. The demographic characteristics of teachers, parents, and students in the study group are presented in Table 2, Table 3, and Table 4, respectively.

Table 2. Demographic features of teachers.

\begin{tabular}{ccccc}
\hline Teachers & Gender & Major & $\begin{array}{c}\text { Professional Experience } \\
\text { (Years) }\end{array}$ & $\begin{array}{c}\text { Educational } \\
\text { Status }\end{array}$ \\
\hline T1 & Female & Turkish & 17 & BA \\
T2 & Male & Science & 25 & BA \\
T3 & Female & Mathematics & 13 & BA \\
T4 & Female & Mathematics & 7 & BA \\
T5 & Male & Social Studies & 5 & MA \\
T6 & Female & Science & 9 & PhD \\
T7 & Male & Turkish & 14 & BA \\
T8 & Female & Science & 15 & BA \\
T9 & Female & Social Studies & 21 & BA \\
\hline
\end{tabular}

As has been shown in Table 2, six of the teachers participating in the research are female, and three are male. According to the branches, two Turkish, two mathematics, three science, and two social studies teachers have participated in the study. The professional experience level of three teachers is between 5-10 years, the professional experience level of four is between 1120 years, and the professional experience level of two is between 21-25 years. According to 
their educational status, it has been observed that seven teachers have BA degrees, one has an MA degree, and one has a $\mathrm{PhD}$ degree.

Table 3. Demographic features of students.

\begin{tabular}{ccc}
\hline Students & Gender & Grade Level \\
\hline S1 & Male & $8^{\text {th }}$ \\
S2 & Male & $7^{\text {th }}$ \\
S3 & Female & $6^{\text {th }}$ \\
S4 & Female & $7^{\text {th }}$ \\
S5 & Male & $8^{\text {th }}$ \\
S6 & Female & $6^{\text {th }}$ \\
S7 & Male & $6^{\text {th }}$ \\
S8 & Female & $7^{\text {th }}$ \\
S9 & Female & $8^{\text {th }}$ \\
\hline
\end{tabular}

As has been presented in Table 3, four male and five female students have participated in the study. Three of the students are at the sixth grade, three of them are at the seventh grade, and the other three are at the eighth grade.

Table 4. Demographic features of parents.

\begin{tabular}{ccc}
\hline Parents & Gender & Educational Status \\
\hline P1 & Female & Junior College \\
P2 & Male & Undergraduate Degree \\
P3 & Female & High School \\
P4 & Male & Primary School \\
P5 & Female & High School \\
P6 & Female & Primary School \\
P7 & Male & Junior College \\
P8 & Female & Undergraduate Degree \\
P9 & Male & Undergraduate Degree \\
\hline
\end{tabular}

Table 4 illustrates that five of the parents who have participated in the study are female, and the other four are male. Two of the parents have graduated from primary school, another two have graduated from high school, another two have graduated from junior college, and the other three parents have graduated from faculties.

\subsection{Data Collection Tools and Techniques}

In this research, the technique of document analysis has been employed to evaluate the cyber accessibility of teacher-made exams collected from schools, and semi-structured interview forms prepared separately for teachers, students, and parents have been utilized to determine the opinions of teachers, parents, and students about cyber accessibility of teacher-made exams.

\subsubsection{Credibility (reliability) and transferability (validity) of the study}

During the document analysis stage of the research, all exam papers have been classified and numbered according to the branches to ensure reliability and validity. First of all, each paper has been examined independently by the researchers, and the question types specific to the branches have been determined. Then, the differences have been eliminated by comparing the tables obtained by the researchers. In the next process, each question has been examined separately by two researchers on search engines, and the cyber accessibility status of questions 
has been recorded. After this stage has been completed, comparisons have been made based on the exam paper, including the sources from which each question has been reached. Thus, a consensus has been reached by proving the evidence for the cyber accessibility of each question by both researchers. At the last stage of the document analysis, one of the researchers has processed the findings obtained according to the branch and question types into the database, and the other researcher has cross-checked and verified the data entry. Thus, internal and external validity and reliability of the first stage of data analysis is assumed to have been ensured.

It should also be noted that interviews have been conducted to support the findings of the document analysis. The findings obtained from the interviews have been analyzed with the technique of content analysis. In the analysis process, the answers to the questions, the repeated concepts, and expressions in each participant form have been compared. In this way, it is thought that a more reliable and valid coding could be made. First of all, the papers belonging to teachers, students, and parents have been named in a representative manner (For example, T1, S1, P1). Following this, each paper has been examined and coded sometimes on the basis of sentences, and sometimes on the basis of paragraphs. As a result, the main ideas have been formed according to themes. Therefore, the codes with repetitive or similar expressions have been simplified and finalized (Bogdan \& Biklen, 2007; Gökçe, 2006). The final decision has been made by determining the similarities and differences in the codes that have been constructed separately by the two researchers. During this process, in order to prevent misunderstandings and misinterpretations, opinions of the third researcher have been obtained about the statements that were ambiguous. The same process has been repeated in all three groups of participants, and frequencies of the codes have been determined after it has been decided that the codes created according to these final code lists completely meet the expressions in answers. The codes that are concluded to be representative of the data and included in the final code list have been classified under certain categories and the analysis process finished (Creswell, 2005; Guba, 1981). The reliability of the analysis has been ensured in two ways. Firstly, the data obtained from the interviews have been coded separately by the first and the second researchers, and then the cases considered to be inconsistent have been reevaluated by making comparisons together. Later, two researchers have come together again and the codes have been compared for a second time, and this time, support has been taken from the third researcher regarding the statements intended to be expressed in some answers. Consequently, the conflicts have been resolved and the codes have been finalized. Thus, in data analysis, the average reliability between coders has been computed as $87 \%$ in the first meetin, and $100 \%$ after the second meeting. These values have been calculated using the formula [((Consensus) / (Agreement + Disagreement) ) x 100] (Miles \& Huberman, 2015). As the second method related to reliability, the observer triangulation method has been used and after comparing two separate analyzes, the resulting categories and codes have been examined by an expert who has not participated in the study to verify the process (Denzin, 1970).

\subsubsection{Document analysis}

In order to determine the cyber accessibility of teacher-made exams for the secondary school Turkish, mathematics, science, social studies/Atatürk's principles and revolutions courses, the data have been collected via the method of document analysis. According to Yıldırım \& Şimşek (2013, p. 217), document review involves the analysis of written materials about the phenomenon or cases to be investigated. In addition to being used as a stand-alone data collection method in qualitative research, document analysis can also be used with different data collection methods. In this research, interview forms have been used together with document review. 


\subsubsection{Teacher, parent and student interview forms}

To determine the opinions of teachers, students, and parents regarding the cyber accessibility of secondary school teacher-made exams, a teacher interview form consisting of seven openended questions; a student interview form consisting of four open-ended questions; and a parent interview form consisting of three open-ended questions have been developed. In the preparation stage of open-ended questions, questions that would enable participants to provide detailed information have been preferred. After reviewing the relevant literature, draft versions of semi-structured interview forms have been developed with the contributions of researchers. As a next step, expert opinions (experts in qualitative research and assessment and evaluation fields) have been collected. Interview forms have been revised in line with the recommendations of the experts. In order to test the intelligibility and relevance of the questions in the revised semi-structured interview forms, the relevant participants (one Turkish, one math teacher, two parents whose children are currently studying at secondary school, and two secondary school students) have been interviewed for each form. As a result of the pilot testing of the interviews, some questions have had to be rearranged and the final versions of interview forms have been obtained.

\subsection{Collection of Data}

Courses that constitute the first stage of the research are Turkish, mathematics, science, social studies/Atatürk's principles and revolutions. Teacher-made exams have been collected from three different secondary schools in Ankara that volunteered to participate in the study. While selecting the schools to be included in the study, voluntariness of the schools has been regarded as essential. However, the researchers have also paid attention to diversity of the schools in terms of academic success, socioeconomic level and facilities. Since the schools only archived the previous year's exam questions, 15 exam papers have been randomly selected from the exams conducted in the 2018-2019 academic year and the first semester of 2019-2020 academic year on the basis of branches. Accordingly, a total of 60 different exam papers have been included in the document review.

In the second stage, teachers', students', and parents' opinions and experiences regarding the cyber accessibility of secondary school teacher-made exams have been obtained using a semistructured interview method. Data have been obtained through face-to-face interviews with nine participants (teachers, students, parents) in each study group by the researcher using the teacher, student, and parent interview forms. Before starting semi-structured interviews, the purpose of the research has been explained to the participants (teacher, student, parent). The participants have been informed that their credentials will remain confidential. For this reason, while expressing the participants' statements, codes have been preferred instead of their real names. Each speech has been transcribed verbatim, in researcher-participant order, without any correction by the researcher.

Firstly, three different secondary school principals in Ankara province have been contacted in order to arrange the meetings with the participants. To be more precise, a separate interview schedule has been created for each participant. Then, on the arranged days and hours, the same schools have been visited by the same researcher, and interviews have been conducted with the participants who volunteered to participate in this research. Interviews have been conducted in the first semester of the 2019-2020 academic year in January. The interviews have been conducted in the deputy principal room of the relevant schools and only the researcher and the participant have been present in the room. The fact that the researcher conducting the interviews is also a teacher made it easier to carry out the interviews with all the participants. 


\subsection{Data Analysis}

\subsubsection{Document analysis}

In the first stage of the research, teacher-made exams of Turkish, mathematics, science, social studies/Atatürk's principles and revolutions courses have been examined via the technique of document analysis. At this stage, firstly, the total number of questions of the exam papers collected for each course has been grouped. As a next step, each exam paper has been examined on a question basis. The cyber accessibility of the questions has been checked using the google search engine. Thus, all questions for each course have been scanned in the search engine and links to the questions have been obtained. The number of questions examined in terms of branches is 437 in Turkish, 348 in Mathematics, 393 in science, and 454 in social studies/Atatürk's principles and revolutions.

\subsubsection{Interview data analysis}

In the analysis of the data obtained in the second stage of the research, descriptive analysis has been used to reveal the opinions, experiences of teachers, students and parents related to the cyber accessibility of secondary school teacher-made exams. The raw data obtained from the interviews have been coded and the categories have been identified. The data have been classified under these categories with the aim of making them meaningful for the reader. The coding and categorization process has been repeated by one of the researchers. Therefore, unnecessary codes have been removed by adhering to the problem and purpose of the research, and new codes have been added in the sections deemed as necessary. The researchers have tagged categories in cooperation. Finally, the tables where the frequency values of the participants' views on the subject have been obtained and examples from the participants' opinions have been included.

\section{RESULT / FINDINGS}

The collected data at this stage have been analyzed for the study. Document analysis has been conducted to determine the cyber accessibility of teacher-made exams and content analysis has been employed to determine the opinions of teachers, students, and parents on this subject. The first question and the findings obtained in the scope of the research are as follows:

\subsection{What is the cyber accessibility level of the secondary school teacher-made exams?}

In order to answer the first question of the study; each course has been examined separately. The findings obtained from the courses are as shown in Table 5. When the Turkish course's cyber accessibility levels presented in Table 5 are analyzed, it is seen that 381 of the 437 questions are cyber accessible. When this ratio is considered based on the question type, it is concluded that multiple-choice and open-ended questions are cyber accessible. However, when 15 different exam papers are evaluated separately, it is seen that all of the questions in 8 exam papers have been taken from different cyber accessible websites and all of the questions in 1 exam paper have been taken from a single website only by changing the name of the school.

When the findings of the mathematics course are examined, 348 questions have been examined and $51 \%$ of these questions are cyber accessible. It has been found that the highest rate is true and false, with $78 \%$. Besides, 15 different exam papers have been examined and it is observed that all of the questions in 4 of them are taken from different cyber accessible websites. The fact that the questions consist mainly of shapes, symbols, and mathematical expressions in mathematics make it difficult for their cyber accessibility; therefore, in each exam paper, firstly verbal phrases have been searched by the researchers. As a result, no exam has been found in which all questions are taken from a single cyber accessible source for the mathematics course. After this stage, the document analysis of the science course questions has started. 
Table 5. Courses cyber accessibility level.

\begin{tabular}{|c|c|c|c|c|c|c|c|}
\hline \multicolumn{2}{|c|}{$\begin{array}{c}\text { Types of Questions } \\
\text { /Courses }\end{array}$} & $\begin{array}{l}\text { Multiple } \\
\text { Choice }\end{array}$ & $\begin{array}{c}\text { Open- } \\
\text { End } \\
\text { Questions } \\
\end{array}$ & $\begin{array}{c}\text { True- } \\
\text { False } \\
\text { Questions } \\
\end{array}$ & $\begin{array}{l}\text { Matching } \\
\text { Questions }\end{array}$ & $\begin{array}{c}\text { Gap-Fill- } \\
\text { ing Ques- } \\
\text { tions }\end{array}$ & Total \\
\hline \multirow[b]{2}{*}{ Turkish } & $\mathrm{NEQ}^{*}$ & 248 & 40 & 5 & 102 & 42 & 437 \\
\hline & $\begin{array}{c}\mathrm{NCAQ}^{* *} \\
(\%) \\
\end{array}$ & $\begin{array}{l}232 \\
(94) \\
\end{array}$ & $\begin{array}{c}27 \\
(94) \\
\end{array}$ & $\begin{array}{c}5 \\
(100) \\
\end{array}$ & $\begin{array}{c}91 \\
(89)\end{array}$ & $\begin{array}{c}26 \\
(62) \\
\end{array}$ & $\begin{array}{l}381 \\
(87) \\
\end{array}$ \\
\hline \multirow[b]{2}{*}{ Mathematics } & NEQ & 179 & 61 & 37 & 34 & 37 & 348 \\
\hline & $\begin{array}{l}\text { NCAQ } \\
(\%)\end{array}$ & $\begin{array}{l}104 \\
(58) \\
\end{array}$ & $\begin{array}{c}12 \\
(20)\end{array}$ & $\begin{array}{c}29 \\
(78) \\
\end{array}$ & $\begin{array}{c}10 \\
(29) \\
\end{array}$ & $\begin{array}{c}22 \\
(59) \\
\end{array}$ & $\begin{array}{l}177 \\
(51)\end{array}$ \\
\hline \multirow[b]{2}{*}{ Science } & NEQ & 186 & 12 & 76 & 96 & 23 & 393 \\
\hline & $\begin{array}{c}\text { NCAQ } \\
(\%)\end{array}$ & $\begin{array}{l}180 \\
(97)\end{array}$ & $\begin{array}{c}12 \\
(100)\end{array}$ & $\begin{array}{c}76 \\
(100) \\
\end{array}$ & $\begin{array}{c}96 \\
(100) \\
\end{array}$ & $\begin{array}{c}23 \\
(100) \\
\end{array}$ & $\begin{array}{r}387 \\
(99) \\
\end{array}$ \\
\hline $\begin{array}{l}\text { Social Studies } \\
\text { / Atatürk's }\end{array}$ & NEQ & 220 & 11 & 25 & 171 & 27 & 454 \\
\hline $\begin{array}{l}\text { Principles and } \\
\text { Revolutions }\end{array}$ & $\begin{array}{l}\text { NCAQ } \\
(\%)\end{array}$ & $\begin{array}{l}210 \\
(96)\end{array}$ & $\begin{array}{c}11 \\
(100)\end{array}$ & $\begin{array}{l}15 \\
(60)\end{array}$ & $\begin{array}{l}141 \\
(83)\end{array}$ & $\begin{array}{c}22 \\
(82)\end{array}$ & $\begin{array}{l}399 \\
(87)\end{array}$ \\
\hline
\end{tabular}

*NEQ: Number of Examined Questions; ${ }^{* *}$ NCAQ: Number of Cyber Achievable Questions

A total of 393 questions related to science course have been examined and the cyber accessibility rate is found to be $99 \%$. When the cyber accessibility rates of all question types are examined in Table 5, it is seen that all of them are very high. However, it has been observed that 5 of 15 different exam papers are taken from various cyber accessible websites and 9 of them are taken from a single website only by changing the name of the school. As a result, all of the questions in science course have been taken from cyber accessible sources. After this stage, Social studies/Atatürk's principles and revolutions course questions' document analysis has started.

When the cyber accessibility level of Social studies/Atatürk's principles and revolutions course is examined, it is seen in Table 5 that 399 of 454 questions are cyber accessible. When this ratio is examined on the basis of question type, it is concluded that most open-ended questions are cyber accessible. However, when 15 different exam papers have been analyzed separately, it is observed that all of the questions in 7 exam papers are taken from different cyber accessible websites and all of the questions in 5 exam papers are taken from one website only by changing the name of the school.

In general, 1632 different questions from a total of 4 courses have been examined. As a result, the cyber accessibility ratio of these questions is computed as $82 \%$. The question types are grouped under 5 different categories. In these categories, 833 multiple-choice, 124 open-ended, 143 true-false, 403 matching and 129 gap-filling questions have been examined. According to the question types, cyber accessibility rates are calculated as $87 \%$ for multiple-choice; $50 \%$ for open-ended; $87 \%$ for true-false; $84 \%$ for matching; and $72 \%$ for gap-filling. In other words, cyber accessibility rates are highest in multiple-choice and true-false questions and lowest in open-ended questions. Although the addresses where the questions are taken differ according to each branch, when the frequencies are examined, it has been found that certain addresses are common in all branches.

\subsection{Findings from Interviews with Teachers, Students, and Parents}

In the tables, the results obtained from the participants are presented for each question posed. 


\subsubsection{Opinions of teachers}

3.2.1.1. Question 1. "Have you received any training on question preparation techniques in measurement and evaluation? Was this training enough for you? Why?" The frequency values of the teachers' answers to Question 1 are presented in Table 6.

Table 6. Teachers' opinions on question 1.

\begin{tabular}{|c|c|c|c|}
\hline Categories & Codes & $f$ & $\%$ \\
\hline \multirow{2}{*}{ Education status } & I took it as an undergraduate course & 7 & 26 \\
\hline & I attended the training of a private institution & 2 & 7 \\
\hline \multirow[t]{2}{*}{ Qualifications } & Sufficient & 0 & 0 \\
\hline & Insufficient & 9 & 33 \\
\hline \multirow[t]{3}{*}{ Causes } & $\begin{array}{l}\text { Education remains at a theoretical level and not } \\
\text { practiced }\end{array}$ & 8 & 30 \\
\hline & Change of educational system & 1 & 4 \\
\hline & Total & 27 & 100 \\
\hline
\end{tabular}

According to Table 6, seven of the teachers who have participated in the research state that they have received training on question preparation techniques within the scope of measurement and evaluation course at the undergraduate level. All teachers think that the training they have received is insufficient. According to eight of the teachers, education remains at a theoretical level, and practice is not included. Some teachers expressed their opinions as follows:

The course I took at the university remained very academic; the practice was not included (T3).

The training that I attended in a private institution was a general review regarding the concepts of measurement and evaluation since the time was limited; no question writing was performed (T7).

3.2.1.2. Question 2. "Do you experience any difficulties in preparing the exam questions in the school? Can you give an example?" The frequency values of the teachers' answers to Question 2 are presented in Table 7.

Table 7. Teachers' opinions on question 2.

\begin{tabular}{llll}
\hline Categories & Codes & $f$ & $\%$ \\
\hline $\begin{array}{l}\text { Difficulty } \\
\text { encountered }\end{array}$ & There is & 7 & 44 \\
\hline $\begin{array}{l}\text { Example } \\
\text { difficulty }\end{array}$ & There isn't & 2 & 13 \\
& $\begin{array}{l}\text { Inability to get down to students' level } \\
\text { Not considering him-/herself sufficient in preparing a new } \\
\text { generation question }\end{array}$ & 1 & 31 \\
& Preparing questions for every course outcome & 1 & 6 \\
\hline
\end{tabular}

According to Table 7, seven of the teachers who have participated in the research state that they encounter difficulty preparing the exam questions. Five of the teachers refer to this difficulty as being unable to get down to students' level. Some teachers expressed their opinions as follows:

Students have individual differences, and I find it challenging to get down to their level (T6).

It is difficult to get down to the level of children. To me, it is easy to prepare difficult questions; it is challenging to prepare easy questions. I cannot predict what children can do because I am new to the school (T4). 
The following words of a teacher on the subject are remarkable:

Students are not ready for the new generation questions. I do not consider myself sufficient in preparing new generation questions. We should get training on this subject (T1).

3.2.1.3. Question 3. "What resources do you use while preparing the exam questions for your course? Which of these sources do you use most?" The frequency values of the teachers' answers to Question 3 are presented in Table 8.

Table 8. Teachers' opinions on question 3.

\begin{tabular}{llll}
\hline Categories & Codes & $f$ & $\%$ \\
\hline Utilized resources & Educational websites & 9 & 29 \\
& Supplementary resources (Question bank, resource book etc.) & 5 & 16 \\
& Education Information Network (EIN) & 3 & 10 \\
& Textbook & 3 & 10 \\
& Notes printed on students' notebook & 2 & 6 \\
\hline \multirow{2}{*}{ Most used source } & Educational websites & 8 & 26 \\
& Notes printed on students' notebook & 1 & 3 \\
\hline
\end{tabular}

According to Table 8, it is seen that teachers use multiple sources while preparing their exam questions for their courses. All of the teachers who have participated in the research state that they make use of educational websites while preparing the exam questions. On the other hand, eight teachers note that the most commonly utilized resource is educational websites when preparing exam questions. The following statements by two teachers about the subject are remarkable:

While preparing the exam questions, I benefit mostly from different educational websites because there is an example of a printed and prepared exam. The figure is ready, and Ijust change the questions (T3).

Since it is more up to date, I examine and organize the exam questions I have compiled from different educational websites in terms of subject, attainment, and class level (T5).

\subsubsection{Opinions of Students}

3.2.2.1. Question 1. "Have you ever encountered identical exam questions prepared by your teachers at school in a different place? Where have you seen these questions before?" The frequency values of the students' answers to Question 1 are presented in Table 9.

Table 9. Students' opinions on question 1.

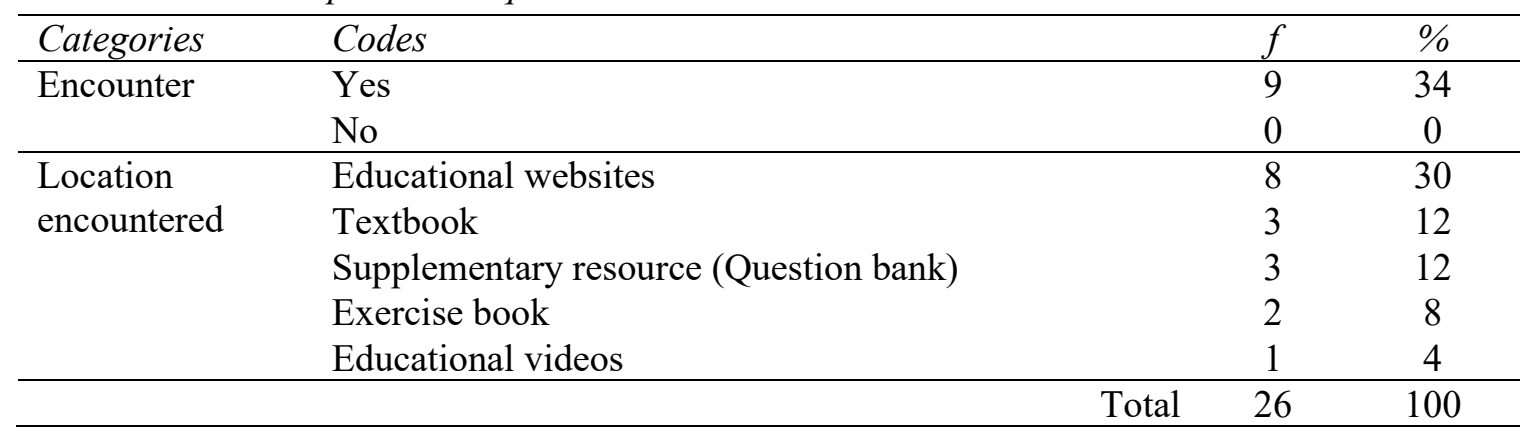

According to Table 9, all of the students' state that they have encountered identical exam questions prepared by their teachers at school in a different place before. Eight of the students who have participated in the study state that they have encountered identical exam questions on educational websites although the sources are different. Some students have expressed their views as follows: 
In the Turkish exam we took last week, there were questions I saw on exam websites on the internet. One of them was the question in the textbook (S3).

In our science exam, there were questions that our teacher solved in the notebook and the questions in the question bank that I solved while preparing for the exam (S7).

3.2.2.2. Question 2. "Which sources do you utilize to prepare for the exams at school?" The frequency values of the students' answers to Question 2 are presented in Table 10.

Table 10. Students' opinions on question 2.

\begin{tabular}{|c|c|c|c|c|}
\hline Category & Codes & & $f$ & $\%$ \\
\hline \multirow[t]{6}{*}{ Utilized resources } & Educational websites & & 8 & 28 \\
\hline & Textbook & & 7 & 24 \\
\hline & Exercise book & & 5 & 17 \\
\hline & Education videos & & 5 & 17 \\
\hline & Supplementary resource (Question bank) & & 4 & 14 \\
\hline & & Total & 29 & 100 \\
\hline
\end{tabular}

According to Table 10, it is seen that students use more than one source while preparing for exams and they mostly benefit from educational websites. The following statements by three students on the subject are remarkable:

While studying for the exam, I usually solve the questions on the internet and read the textbook (S2).

Our teacher watches video in the course and asks the questions at the end of the video. I'm watching those videos too. Also, since I am preparing for LGS (National High School Entrance Exam), I solve tests from the test book (S5).

I usually read the notes our teachers have us write in our notebooks. Most of the time, I solve the questions on educational websites on the internet (S9).

\subsubsection{Opinions of Parents}

3.2.3.1. Question 1. "What resources does/do your child/children going to secondary school currently use when preparing for the exams held by teachers at school? Which of these sources do you think he/she/they uses/use the most? Frequency values regarding the answers given by parents to Question 1 are presented in Table 11 .

Table 11. Parents' opinions on question 1.

\begin{tabular}{llcc}
\hline Categories & Codes & $f$ & $\%$ \\
\hline Utilized resources & Educational websites & 5 & 20 \\
& Supplementary resource (Question bank) & 4 & 16 \\
& Textbook & 3 & 12 \\
& Educational videos & 2 & 8 \\
& Exercise book & 1 & 4 \\
& Republic of Turkey Ministry of National Education achieve- & 1 & 4 \\
& ment tests & & \\
\hline \multirow{3}{*}{ Most used source } & Educational websites & 3 & 12 \\
& Supplementary resource (Question bank) & 3 & 12 \\
& Textbook & 1 & 4 \\
& Educational videos & 1 & 4 \\
& Exercise book & 1 & 4 \\
\hline & & 25 & 100 \\
\hline
\end{tabular}


According to Table 11, parents whose children attend secondary schools state that their children use more than one source while they are preparing for the exams held by teachers at school. Five of the parents who have participated in the study state that they use educational websites while preparing them for the exams at school. Three parents note that the most commonly used resource their children use to prepare for the exams held in school is the educational websites. Moreover, three parents refer to supplementary resources as the most commonly utilized sources. The following view of a parent on the subject is remarkable:

While my eldest son was going to middle school, we were downloading questions from the websites that had written questions on the internet to prepare them for exams. He solved these questions because the same questions appeared in the test and he was getting high marks. But this was not his real score. He scored low in TEOG (The Evaluation of the Transition Model from Elementary to Higher Education) and accepted by a high school he did not want. Therefore, I am not making the same mistake with my younger son. We do not solve any questions from that website. We use the MEB (Ministry of National Education) acquisition tests and continue from the sourcebooks (P3).

Another parent has expressed his/her opinion as follows:

When my daughter has an upcoming exam, she reads the topics from her textbook and from her supplementary sources in her room. Then, she solves exam questions from the websites she finds on the Internet and solves the questions and checks her mistakes from the supplementary resources she made us bought for her. As far as I can see, she spends most of her time on the computer and solves questions from internet sites (P6).

\section{DISCUSSION and CONCLUSION}

This study aims at obtaining the cyber accessibility levels of the secondary school teacher-made exams and the opinions of teachers, students, and parents on this subject. According to the results, the level of cyber accessibility of secondary school teacher-made exams for each course is as follows: $87 \%$ for Turkish, $51 \%$ for mathematics, $99 \%$ for science and $88 \%$ for social studies/ Atatürk's principles and revolutions. When the question types are examined, the highest cyber accessibility level is observed in multiple-choice and true-false questions. It is clear that the most common question type in the question papers is multiple choice and these results are consistent with those of Kilıç (2016) and Uymaz (2016).

Another remarkable finding at the end of the study is that $82 \%$ of all the questions are cyber accessible. This result is important in terms of questioning the reliability of teacher-made exams. In a similar vein, Sinaci examined teacher-made exams before and after TEOG in his study in 2019 and found that in some schools, students' scores in pre-TEOG teacher-made exams and in TEOG are inconsistent. Furthermore, post-TEOG teacher-made exams show higher correlations than pre-TEOG teacher-made exams with TEOG. It was stated that the placement scores obtained from the TEOG system were not calculated fairly because the results of the teacher-made exams were tried to be equated to TEOG results. Similarly, the study by Antenesh and Silesh (2018) found a positive but low correlation between teacher-made exams and regional exam results $(\mathrm{r}=0.476, p<0.01)$. The study conducted by Özdemir \& Gelbal (2016) with the aim of investigating the predictive power of the same students' end-of-the-year achievement score from 7th to 12th grade on the raw scores of YGS sub-exams concludes that the best predictor of mathematics, Turkish, science, and social sciences sub-tests is the end-ofthe-year achievement score of different courses at different grade levels and these variables explain $50 \%$ to $71 \%$ of success in the relevant sub-tests. These results indicate that teachermade exams are not sufficient in terms of measurement and evaluation criteria.

When the teacher's opinions are examined, a vast majority of teachers state that they have problems in the measurement and evaluation process. Similarly, according to the research 
results of Zorbaz (2005), most of the Turkish language teachers considered determining whether the subjects are comprehended or not and grading with the purpose of measurement and evaluation. As a matter of fact, it has been identified that the teachers who have participated in the study generally received their training on question preparation techniques within the scope of the 'measurement and evaluation' course given during their undergraduate years. Furthermore, it has been understood that this education remained at the theoretical level and the education received is insufficient because it did not include any practice dimension. The teachers state that they mostly encounter difficulties while preparing the exam questions due to their inability to reach the student level. Teachers also complain that that they cannot write questions covering all subjects and do not perceive themselves competent in preparing new generation questions, leading to difficulties in preparing exam questions. Similarly, it was found that teacher-made exam questions examined by Uymaz (2016) and Zorbaz (2005) were mostly at the level of knowledge and comprehension and they did not include many questions at the metacognitive level.

In a similar fashion, teachers have remarked that they mostly benefit from educational websites while preparing their exam questions. In the document analysis process of the research, although the exam questions have been scanned separately as root and options, it has been observed that both the root and the options of the questions have been taken from cyber accessible educational sites without any modifications. The most important reason for this may be that teachers do not have sufficient knowledge about measurement and evaluation techniques. In addition, it has also been observed that there are several common addresses for each course. To be more precise, while all of the questions on certain exam papers could be accessed from various websites, it has also been noticed that on some exam papers, all questions were taken from a single cyber accessible source. When the student opinions on the cyber accessibility of teacher-made exams are examined, it is monitored that these opinions support the results obtained from the document examination. Accordingly, all of the students who have participated in the study state that they have encountered some of the exam questions prepared by their school teachers on educational websites. For this reason, it has been admitted that educational websites are the most beneficial sources for students while taking advantage of multiple resources during school exams.

As to the parents' views on the cyber accessibility of teacher-made exams, the parents who have participated in the study believe that while their children prepare for the exams conducted by the teachers at school, they benefit from more than one source; however, they mostly use educational sites and supplementary resources (such as sourcebooks and question banks). Most significantly, it has been observed that both parents and students are aware of the cyber accessibility of teacher-made exams. Therefore, they tend to guide their children to the questions on the cyber accessible websites to ensure high scores in teacher-made exams at the cost of low scores in the central exam. This result supports the findings of studies conducted by Antenesh \& Silesh (2018) and Sinaci (2019). To sum up, the cyber accessibility of teachermade exam questions prepared for four basic courses at the secondary school level; namely, Turkish, mathematics, science and social studies/Atatürk's principles and revolutions, is high and since this is known by both the students and the parents, it would be justified to argue that the reliability level of these exams is low. This study is limited to teacher-made exams collected for 4 basic courses and the participants in three secondary schools in Ankara. This situation requires the repetition of the study in different levels, schools and courses in order to support the results obtained from the research theoretically. In order to increase the quality of teachermade exams, it is recommended to organize trainings for teachers on question preparation techniques. 


\section{Declaration of Conflicting Interests and Ethics}

The authors declare no conflict of interest. This research study complies with research publishing ethics. The scientific and legal responsibility for manuscripts published in IJATE belongs to the authors. Ethics Committee Number: Suleyman Demirel University, 14.09.2020-96/13.

\section{Authorship Contribution Statement}

Gulden Ozdemir: Investigation, Resources, Visualization, Software, Formal Analysis. Atilla Ozdemir: Investigation, Resources, Visualization, Software, Formal Analysis, and Writing original draft. Selahattin Gelbal: Methodology, Supervision, and Validation.

\section{ORCID}

Gulden Ozdemir (D) https://orcid.org/0000-0002-3150-9438
Atilla Ozdemir (D) https://orcid.org/0000-0003-4775-4435
Selahattin Gelbal (iD https://orcid.org/0000-0001-5181-7262

\section{REFERENCES}

AERA, APA, \& NCME (2014). Standards for educational and psychological testing. American Educational Research Association.

Akar, Z. (2019). Sekizinci sınıf Türkçe dersi yazılı sorularının merkezî sınav Türkçe soruları ile karşllaştırllması [Comparison of eighth grade Turkish course written questions with central exam Turkish questions] [Unpublished master's thesis]. Ataturk University.

Anteneh, M. M., \& Silesh, B. D. (2018). Assessment practices and factors for the disparity between students' academic scores at teacher-made and regional exams: The case of Bench Maji zone grade 8 students. Educational Research and Reviews, 14(1), 1-24. https://doi.org/10.5897/ERR2018.3581

Ardahanlı, Ö. (2018). TEOG sinavı matematik soruları ile 8. sinif matematik yazllı sinav sorularınin yenilenmiş bloom taksonomisi'ne göre incelenmesi [Analysis of questions in the TEOG examination and questions in the mathematics written exam of $8^{\text {th }}$ grade mathematics courses according to the revised bloom's taxonomy] [Unpublished master's thesis]. Eskisehir Osmangazi University.

Ateş, D. (2016). Possibilities of democracy transformation in cyberworld: the case of legislation assemblies. Cyberpolitik Journal, 1(1), 170-177.

Aytaç, K. (1999). Federal Almanya Cumhuriyeti'nde okul sistemi [School system in the Federak Republic of Germany]. Engin Yayınevi.

Bakırcı, G. (2019). Ortaokul matematik ögretmenlerinin veri öğrenme alanına dair yazllı sınav sorulart ile pisa sorularının karşılaştırmalı incelemesi [Comparative investigation of the secondary school mathematics teachers written exam questions and PISA questions in the field of data handling] [Unpublished master's thesis]. Gaziantep University.

Bal, B., \& Başar, E. (2014, Ocak). Finlandiya, Almanya, Singapur ve Türkiye'nin eğitim sistemleri açısından kademeler arası geçiş sistemlerinin karşılaştırılması [The comparison the systems of passing among educational levels of Finland, Germany, Singapore and Turkey]. Çukurova Üniversitesi Türkoloji Makale Bilgi Sistemi, 18776, 1-24.

Baykul, Y. (2010). Eğitimde ve psikolojide ölçme: Klasik test teorisi ve uygulaması [Measurement in education and psychology: Classical test theory and practice]. (2. Bask1). Pegem Akademi.

Bogdan, R.C., \& Biklen, S.K. (1992). Qualitative research for education: A introduction to theory and methods. Allyn and Bacon.

Büyüköztürk, Ş. (2016). Sınavlar üzerine düşünceler - Türkiye'de ki ölçme değerlendirme sistemi üzerine güncel durum hakkında uzman değerlendirmesi [Thoughts on exams - 
expert assessment on the current situation on the assessment system in Turkey]. Kalem Eğitim ve Insan Bilimleri Dergisi, 6(2), 345-356.

Creswell, J. W. (2005). Educational research: Planning, conducting and evaluating quantitative and qualitative research. Upper Saddle River, Pearson Education, Inc.

Demircioğlu, G., \& Demircioğlu, H. (2009). Kimya öğretmenlerinin sınavlarda sordukları soruların hedef davranışlar açısından değerlendirilmesi [An evaluation of the questions chemistry teachers asked in exams in terms of the target behaviors]. Necatibey Faculty of Education Electronic Journal of Science and Mathematics Education, 3(1), 80-98.

Denzin, N. K. (1978). The research act: A theoretical orientation to sociological methods. McGraw-Hill.

Göçkan, A. (2019). Türk eğitim sistemi ile Alman ĕgitim sisteminde kademeler arası geçişlerin karşılaştırllması [Comparison between the Turkish education system and the levels in the German education system] [Unpublished master's thesis]. Canakkale Onsekiz Mart University.

Gökçe, O. (2006). Içerik analizi: kuramsal ve pratik bilgiler [Content analysis: theoretical and practical information]. Siyasal Kitabevi.

Guba, E. G. (1981). Criteria for assessing the trustworthiness of naturalistic inquiries. Educational Communication and Technology: A Journal of Theory, Research, and Development, 29(2), 75-91.

Kılıç, A. F. (2015). Temel eğitimden ortaöğretime geçiş ortak ve mazeret sınavindaki Türkçe ve matematik alt testlerinin psikometrik özelliklerinin karşılaştırılması [The comparison of psychrometric properties of standardised and make up maths and Turkish subtest questions in the exam of transition from basic to secondary education] [Unpublished master's thesis]. Hacettepe University.

Kilmen, S. (2014). Ölçme ve değerlendirmede temel kavramlar, R. N. Demirtaşlı (Ed.), Eğitimde ölçme ve değerlendirme içinde /Basic concepts in measurement and evaluation, R. N. Demirtaşlı (Ed.), in Measurement and evaluation in education] (s. 30-64). Edge Akademi.

MEB (2019). Ortaöğretime geçiş tercih ve yerleştirme kılavuzu [The Guidelines for Transition to Secondary Education]. http://www.meb.gov.tr/meb_iys_dosylar/2019 06/25104443 evrak8071216911865128306.pdf

Miles, M. B., \& Huberman, A. M. (2015). Nitel veri analizi [Qualitative data analysis] (2. baskıdan çeviri) (S. Akbaba Altun, \& A. Ersoy Çev. Eds). Pegem Akademi.

Önder, R. (2016). 2014-2015 TEOG sinavına ilişkin paydaş görüşleri ile öğretmen yapımı testlerle olan ilişkisi [Relationship between basis of stakeholders opinion about TEOG with teachers making test in 2014-2015] [Unpublished master's thesis]. Akdeniz University.

Özdemir, A., \& Gelbal, S. (2016). Predictive power of primary and secondary school success criterion on transition to higher education examination scores. Journal of Measurement and Evaluation in Education and Psychology, 7(2), 309-334.

Özdemir, S., \& Şahin, Ş. (2005). Siberuzay nerede? [Where is the cyberspace?]. Pivolka, 4(19), 1-14.

Patton, M. Q. (2005). Qualitative research. John Wiley \& Sons, Ltd.

Shariff, S., \& Gouin, R. (2005, November). Cyber-dilemmas: Gendered hierarchies, free expression and cyber-safety in schools. In Oxford Internet Institute conference at Oxford University.

Sınacı, B. (2019). Temel ĕ̆itimden ortaöğretime geçiş (teog) sisteminde uygulanan sinavların puanları ile diğer puanların karşılaştırllması [The comparison of scores in transition from basic education to secondary education (TEOG) and other scores] [Unpublished master's thesis]. Hacettepe University. 
Turan, S. D. (2017). Ortaokul 5, 6, 7 ve 8. sinıffen bilimleri dersi yazıll sınav sorularının ölçme ve değerlendirmeye uygunluğu açısından incelenmesi [An investigation on the written examinations of the science courses of 5, 6, 7 and 8 th grade with regard to the appropriateness of measurement and evaluation] [Unpublished master's thesis]. Mustafa Kemal University.

Uymaz, M., \& Çalışkan, H. (2019). Öğretmen yapımı sosyal bilgiler dersi sınav sorularının yenilenmiş bloom taksonomisine göre incelenmesi [An investigation on the teacher-made social studies course exam questions in terms of revised Bloom's taxonomy]. Kastamonu Education Journal, 27(1), 331-346. https://doi.org/10.24106/kefdergi.2637

Wang J, Iannotti RJ, \& Nansel TR. (2009). School bullying among adolescents in the United States: physical, verbal, relational, and cyber. Journal of Adolescent Health, 45(4), 36875.

Yıldırım, A., \& Şimşek, H. (2013). Sosyal bilimlerde nitel araştırma yöntemleri [Qualitative research methods in the social sciences]. Seçkin Yayınevi.

Zorbaz, K. Z. (2005). Illköğretim okullart ikinci kademe türkçe öğretmenlerinin ölçme ve değerlendirmeye ilişkin görüşleri ve yazıl sinavlarda sordukları sorular üzerine bir değerlendirme [An evaluation on the views of primary school Turkish teachers on measurement and evaluation and the questions they ask in written examinations] [Unpublished master's thesis]. Mustafa Kemal University. 